\title{
Integrated Approach of Yoga Therapy towards Chronic Low Back Pain: A Case Report
}

\author{
Reshma P. Jogdand ${ }^{1 *}$, Shekhar Mukhiya Sunuwar ${ }^{2}$, Amit Singh ${ }^{3}$ and R. Nagrathna ${ }^{4}$ \\ Department of Life Sciences, SVYASA University, Bangalore ${ }^{1,3,4}$ \\ The School of Yoga and Naturopathic Medicine, SVYASA University, Bangalore ${ }^{2}$
}

\section{KEY WORDS}

Lower back pain

Yoga therapy

Naturopathy

Physiotherapy

Quality of life

*Corresponding Author:

Reshma P. Jogdand

Department of Life Sciences,

SVYASA University, Bangalore

Contact no: +91-9449164937

E-mail: reshma.bnys@gmail.com

\begin{abstract}
This case report represents the patient of lower back pain (LBP) who visited Arogyadhama (SVYASA University, Bangalore). Patient was suffering from low back pain and multiple joint pain at the time of visit and 14 days Yoga intervention was provided to the patient for pain management, which helped the patient in relieving the pain and improving the muscular strength and quality of life significantly. The present case study is an attempt to provide IAYT (Integrated approach of Yoga therapy) practices in combination with naturopathy and physiotherapy for the maintenance of LBP profile and symptoms.
\end{abstract}

doi: 10.38205/imcr.020115

\section{Introduction}

Chronic low back pain (CLBP) is a chronic pain syndrome of the lower back region lasting at least for 3 months. It is the most common musculoskeletal condition affecting the adult population. Many authors define CLBP as pain that lasts beyond the expected period of healing (1). CLBP is a main cause of physical disability worldwide and needs significant government assistance and financial help to resolve the issue (2). Non-specific LBP does not have any recognizable pathology (such as infection, tumor, osteoporosis, rheumatoid arthritis, fracture, or inflammation) and traits (3).

Commonness of incessant LBP IS $4.2 \%$ among the adults in the age group of 24 to 39 years and $19.6 \%$ among 20 to 59 years (5). Among nine investigations, six show prevalence of LBP in about 3.9\%-10.2\% people aged 18 or more, whereas other three investigations shows prevalence range of the same between $13.1 \%$ and $20.3 \%$. LBP predominance was noticed $25.4 \%$ among Brazilian population while it was 15 to $45 \%$ in French human services laborers. Pervasiveness of CLBP is evaluated to be $5.91 \%$ in Italy (2). The prevalence of acute and CLBP in adults doubled in the last decade and continues to increase dramatically in the aging population, affecting both men and women in all ethnic groups (6).

Side effects, pathology, and radiological appearances are ineffectively associated with CLBP. Intensity of pain is indefinite in about $85 \%$ of individuals suffering from CLBP. About $4 \%$ of individuals with CLBP in essential consideration has pressure breaks, and about $1 \%$ are known to be associated with tumor. The commonness of prolapsed intervertebral plate among individuals with CLBP is about $1 \%$ to $3 \%$, while Ankylosing spondylitis and spinal diseases are more uncommon. These findings can't be used for an authoritative conclusion on incessant LBP. Different factors, other than physical, may be associated with progression of CLBP which includes hazard factors such as substantial physical work, bowing, turning, lifting and Psychosocial chance elements, such as nervousness, gloom, and mental worry, at work. Having a past history of LBP and a more extended span of critical hazard factors for chronicity. One efficient survey of described that some mental components such as trouble, burdensome state of mind, and somatization are related with an expanded danger of constant LBP. Working environment and individual factors are also thought to be associated with the progress of interminable LBP (4).

\section{Case presentation}

\section{Recruitment of patient}

A 51 year old female from Telengana who visited Prashanti Kutiram (Arogyadhma) SVYASA for treatment of her CLBP was enrolled as a participant for this case study after taking her written consent and explaining her about the treatment regimen. She was kept in section 'E', which deals with spinal disorders and back pain. She resided in the campus for a period of 14 days (6 $6^{\text {th }}$ March, 2020 to $19^{\text {th }}$ March, 2020). Yoga therapy, which included loosening practices (Table 1), Pranayams (Table 2), breathing practices (Table 3) and asanas 
(Table 4) was combined with Naturopathy (Table 5) and Physiotherapy (Table 6)s for her CLBP treatment. Specific diet plan (Table 7) was also followed by participant. Below is a treatment regimen that was provided to the patient during her stay in SVYASA.

\section{IAYT Protocol}

\section{Treatment Regimen}

\section{Loosening Practice (7)}

Table 1: Loosening practices followed by participant

\begin{tabular}{|c|l|l|l|l|}
\hline $\begin{array}{c}\text { S. } \\
\text { No. }\end{array}$ & Practice & $\begin{array}{l}\text { Duration } \\
\text { per session }\end{array}$ & $\begin{array}{l}\text { Frequency } \\
\text { per day }\end{array}$ & $\begin{array}{l}\text { Duration of } \\
\text { intervention }\end{array}$ \\
\hline 1 & Ankle movement & 10 times & 2 times a day & 2 weeks \\
\hline 2 & $\begin{array}{l}\text { Feet movement } \\
\text { inward-outward }\end{array}$ & 10 times & 2 times a day & 2 weeks \\
\hline 3 & Ankle rotation & 10 times & 2 times a day & 2 weeks \\
\hline 4 & Butterfly & 20 times & 2 times a day & 2 weeks \\
\hline 5 & St. leg raising & 5 times & 2 times a day & 2 weeks \\
\hline 6 & $\begin{array}{l}\text { Shoulder } \\
\text { Rotation }\end{array}$ & 10 times & 2 times a day & 2 weeks \\
\hline 7 & $\begin{array}{l}\text { Upper arm } \\
\text { stretch }\end{array}$ & 10 times & 2 times a day & 2 weeks \\
\hline 8 & $\begin{array}{l}\text { Vertical stretch } \\
\text { of knee }\end{array}$ & 10 times & 2 times a day & 2 weeks \\
\hline 9 & Neck movement & 10 times & 2 times a day & 2 weeks \\
\hline 10 & Side leg raising & 10 times & 2 times a day & 2 weeks \\
\hline 11 & $\begin{array}{l}\text { Alternate foot } \\
\text { knee }\end{array}$ & 10 times & 2 times a day & 2 weeks \\
\hline 12 & $\begin{array}{l}\text { Sideward } \\
\text { bending }\end{array}$ & 10 times & 2 times a day & 2 weeks \\
\hline 13 & Cross leg L.S & 10 times & 2 times a day & 2 weeks \\
\hline 14 & Hip stretch & 10 times & 2 times a day & 2 weeks \\
\hline 15 & $\begin{array}{l}\text { Back stretch with } \\
\text { alternate leg }\end{array}$ & 10 times & 2 times a day & 2 weeks \\
\hline 16 & Full butterfly & 10 times & 2 times a day & 2 weeks \\
\hline 17 & $\begin{array}{l}\text { Alternate } \& \text { both } \\
\text { leg raising }\end{array}$ & 10 times & 2 times a day & 2 weeks \\
\hline 18 & Side leg raising & 10 times & 2 times a day & 2 weeks \\
\hline
\end{tabular}

\section{Pranayama (8)}

Table 2: Pranayams followed by participant

\begin{tabular}{|l|l|l|l|l|}
\hline & Pranayama & $\begin{array}{l}\text { Duration of } \\
\text { procedure }\end{array}$ & Frequency & $\begin{array}{l}\text { Duration of } \\
\text { Intervention }\end{array}$ \\
\hline 1 & $\begin{array}{l}\text { Nadishuddhi } \\
\text { Pranayama }\end{array}$ & $\begin{array}{l}\text { 27 Rounds } \\
\text { for each } \\
\text { nostril }\end{array}$ & 4 times a day & 2 weeks \\
\hline 2 & Brahmari & 9 Rounds & 2 times a day & 2 weeks \\
\hline 3 & Naadaanusandhna & 5 Rounds & 2 times a day & 2 weeks \\
\hline
\end{tabular}

\section{Deep Relaxation Technique (10-15 minutes) (9)}

Each session of passive exercise, pranayama was completed with D.R.T. (Deep Relaxation Technique). Deep Relaxation Technique (D.R.T.) is a deeper and more intense form of relaxation. For making participant comfortable during relaxation session, DRT was done in Savasana (Corpse Pose) because it is generally done for 15 minutes.

\section{Breathing Practices (10)}

Table 3: Breathing practices followed by participant

\begin{tabular}{|c|l|l|l|l|}
\hline $\begin{array}{c}\text { S. } \\
\text { No. }\end{array}$ & $\begin{array}{l}\text { Breathing } \\
\text { Practices }\end{array}$ & $\begin{array}{l}\text { Duration of } \\
\text { procedure }\end{array}$ & Frequency & $\begin{array}{l}\text { Duration of } \\
\text { Intervention }\end{array}$ \\
\hline 1 & $\begin{array}{l}\text { Hand Stretch } \\
\text { Breathing }\end{array}$ & 2 minutes & 2 times a day & 2 weeks \\
\hline 2 & $\begin{array}{l}\text { Hands In and } \\
\text { Out Breathing }\end{array}$ & 2 minutes & 2 times a day & 2 weeks \\
\hline 3 & $\begin{array}{l}\text { Ankle stretch } \\
\text { Breathing }\end{array}$ & 2 minutes & 2 times a day & 2 weeks \\
\hline 4 & Tiger Breathing & 2 minutes & 2 times a day & 2 weeks \\
\hline
\end{tabular}

\section{Yogasana (11)}

Table 4: Asanas followed by participant

\begin{tabular}{|l|l|l|l|l|}
\hline & Yogasanas & $\begin{array}{l}\text { Duration of } \\
\text { procedure }\end{array}$ & Frequency & $\begin{array}{l}\text { Duration of } \\
\text { Intervention }\end{array}$ \\
\hline 1 & Standing Position & & & \\
\hline 1 & sasankasana & 2 minutes & 2 times a day & 2 weeks \\
\hline 2. & $\begin{array}{l}\text { Dorsal stretch } \\
\text { (naukasana) }\end{array}$ & 2 minutes & 2 times a day & 2 weeks \\
\hline 3 & $\begin{array}{l}\text { Pavanmuktasanakriya } \\
\text { (without lifting the } \\
\text { head) }\end{array}$ & 2 minutes & 2 times a day & 2 weeks \\
\hline 4. & Bhujanagasana & 2 minutes & 2 times a day & 2 weeks \\
\hline 5 & Dorsal stretch & 1 minute & 2 times a day & 2 weeks \\
\hline 6 & salabhasana & 2 minutes & 2 times a day & 2 weeks \\
\hline 7 & Walking & & 2 times a day & 2 weeks \\
\hline 8 & Side leg raising & 1 minute & 2 times a day & 2 weeks \\
\hline
\end{tabular}

\section{Naturopathy (12)}

Table 5: Naturopathy treatment followed by participant

\begin{tabular}{|c|l|l|l|l|}
\hline $\begin{array}{c}\text { S. } \\
\text { No. }\end{array}$ & Treatments & $\begin{array}{l}\text { Duration } \\
\text { (minutes) }\end{array}$ & Frequency & Periods \\
\hline 1 & Mud pack & 15 & 1 time a day & 1 week \\
\hline 2 & Salt water bath & 45 & 1 time a day & 1 week \\
\hline 3 & Mustard pack & 30 & 1 time a day & 1 week \\
\hline 4 & Hot fomentation & 15 & 1 time a day & 1 week \\
\hline 5 & Vibro massage & 15 & 1 time a day & 1 week \\
\hline
\end{tabular}




\section{Physiotherapy (13)(14)}

Table 6: Physiotherapy treatment followed by participant

\begin{tabular}{|c|l|l|l|l|}
\hline $\begin{array}{c}\text { S. } \\
\text { No. }\end{array}$ & Treatments & $\begin{array}{l}\text { Duration } \\
\text { (minutes) }\end{array}$ & Frequency & Periods \\
\hline 1 & ix. IFT & 5 & 1 time a day & 1 week \\
\hline 2 & x. Ultrasound & 5 & 1 time aday & 1 week \\
\hline
\end{tabular}

\section{Diet Protocol (8)}

The participant was advised to take naturopathic diet consecutively for 14 days of her stay in Prashanti kuteeram. The pattern was as follows.

Lunch: (boiled diet) 1 chapati, 1 cup adl, 1 cup rice, buttermilk, 100 gm boiled vegtables (beans + pumpkin + beetroot + methi + spinach + knolkhol)

Dinner: (Raw diet) 2-3 slices fruits (papaya + watermelon + pomegranate/muskmelon), Vegetable salad (cucumber + pomegranate + beetroot + carrot), Butter milk.

\section{Diagnosis}

Reduction of low back pain was noticed.

Table 8: Score of different parameters before and after the treatment regimen

\begin{tabular}{|l|l|l|}
\hline Parameters & DOA & DOD \\
\hline Pulse Beats/min & $80 \mathrm{bpm}$ & $74 \mathrm{bpm}$ \\
\hline BP in mmHg & $130 / 70 \mathrm{~mm} / \mathrm{Hg}$ & $148 / 98 \mathrm{~mm} / \mathrm{Hg}$ \\
\hline Respiratory Cycles/min & $17 \mathrm{cpm}$ & $11 \mathrm{cpm}$ \\
\hline Bhramari Time (Sec) & $15 \mathrm{sec}$ & $15 \mathrm{sec}$ \\
\hline Symptoms score & 03 & 01 \\
\hline $\begin{array}{l}\text { Straight leg raising } \\
\text { Lt/Rt in degree }\end{array}$ & $80 / 80$ & $90 / 90$ \\
\hline Sit and reach & $46 \mathrm{~cm}$ & $47 \mathrm{~cm}$ \\
\hline Pain Scale Reading & 09 & 05 \\
\hline
\end{tabular}

\section{Discussion}

It was observed that the patient was able to maintain a healthy living by adopting IAYT which may have helped improving the patient's overall health. During her stay she had undergone

Table 7: Weekly diet plan followed by participant

\begin{tabular}{|c|c|c|c|c|c|c|c|}
\hline & 8:00 am & 10:00 am & 12:00 pm & 2:00 pm & 5:00 pm & $7: 30 \mathrm{pm}$ & 8:30 pm \\
\hline Saturday & Ash gourd juice & Barley water & Lunch & Buttermilk & Ash gourd juice & Dinner & Kashayam \\
\hline Sunday & Carrot juice & Watermelon & Lunch & Buttermilk & Carrot juice & Dinner & Kashayam \\
\hline Monday & Bottle gourd juice & Musk melon & Lunch & Buttermilk & Bottle gourd juice & Dinner & Kashayam \\
\hline Thuesday & Bottle gourd & Watermelon & Lunch & Buttermilk & Bottle gourd & Dinner & Kashayam \\
\hline Wednesday & Ash guard juice & Carrot juice & Lunch & Buttermilk & Ash guard juice & Dinner & Kashayam \\
\hline Thursday & Carrot juice & Ash guard & Lunch & Buttermilk & & Dinner & Kashayam \\
\hline Friday & Breakfast & - & Pongal + buttermilk & Buttermilk & - & Dinner & - \\
\hline
\end{tabular}

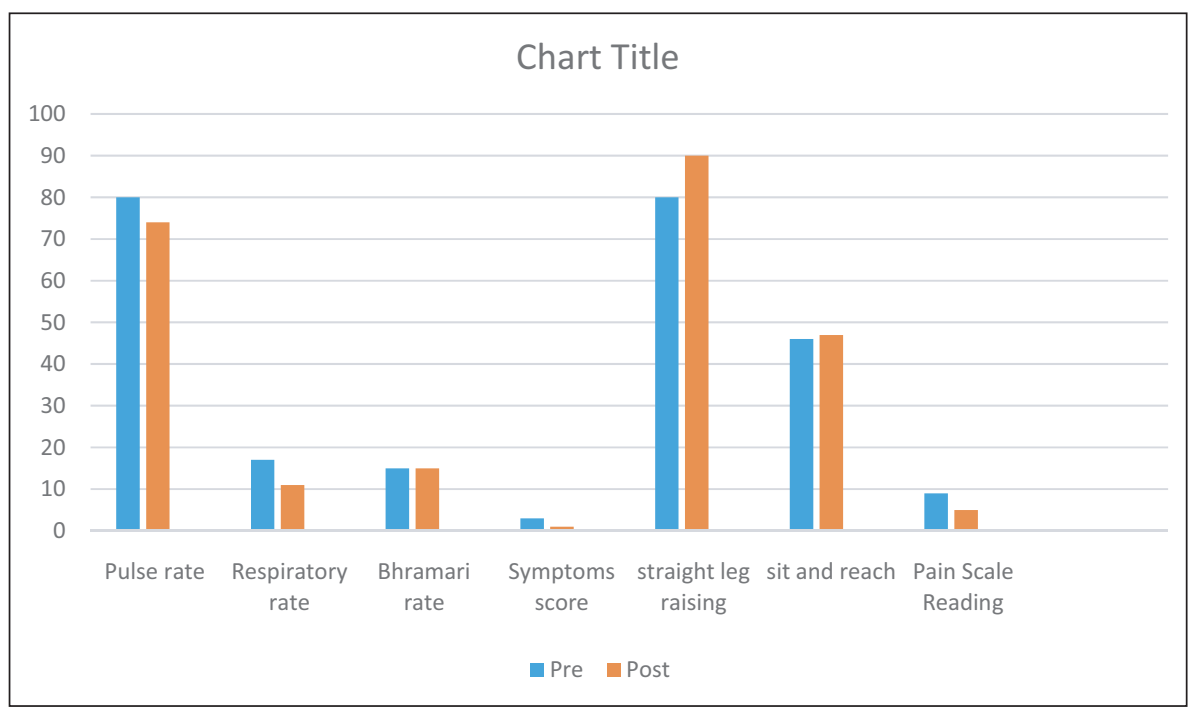

Fig. 1: Bars represent the intensity of different parameters diagnosed during treatment period of 14 days. 
above mentioned yoga practice, meditation, relaxation techniques, Naturopathy treatments and Physiotherapy practices. There was marked positive changes in all vitals including Blood pressure, Respiratory rate and there was significant improvement in symptoms score and good number of reduction in straight leg raising and sit and reach scale.

\section{Conclusion}

Overall treatment of Yoga combined with physiotherapy, naturopathy and specific diet plan helped her to reduce LBP and symptom score such as difficulty in performing day to day activities and disturbed sleep due to pain and helped her to maintain the better quality of life. Above mentioned integrated treatment can be recommended to the patients with CLBP.

\section{Acknowledgement}

First of all, I bestow in front of Lord Dhanavantari and express deepest gratitude to the almighty. In addition I would like to acknowledge the following people who played an instrumental role in the completion of this project. I express my appreciation to the blessings of my gurus and salutations to my parents and all my teachers. I am grateful to Dr. Nagarathna and Dr. Amit Singh of research for sharing their thoughts with other people. Special thanks to a person who motivated me for this work is Dr. Amit singh, his guidance and support makes me more strong and confident to study in this area.

I am appreciative to section therapist for their guidance and allowing me to provide Yoga therapy to their patients and their immense support in my presented work. My love and regards goes to my loving parents for their endless support and encouragement finally, my hearted thank to my husband Mr. Sumit Aundhekar for extending his support through out my work. I express my gratitude to all the Participants, as they were the true inspiration and purpose.

\section{Authorship contribution}

$\mathrm{RJ}$ and SM has written Article.

RN guided to write article.

AS has contributed in a treatment planning.

\section{Informed consent}

Yes.

\section{Source of funding}

Nil.

\section{Conflict of interest}

Nil.
Received Date: 04-07-20; Revised Date: 24-08-20

Accepted Date: 15-09-20

\section{References}

1. Johannes CB, Le TK, Zhou X, Johnston JA, Dworkin RH. The prevalence of chronic pain in United States adults: results of an Internet-based survey. The Journal of Pain. 2010 Nov 1;11(11):1230-9.

2. Allegri M, Montella S, Salici F, Valente A, Marchesini M, Compagnone C, Baciarello M, Manferdini ME, Fanelli G. Mechanisms of low back pain: a guide for diagnosis and therapy. F1000Research. 2016;5.

3. Andersson GB. Epidemiological features of chronic low-back pain. The lancet. 1999 Aug 14;354(9178):581-5.

4. Chou R, Huffman LH. Nonpharmacologic therapies for acute and chronic low back pain: a review of the evidence for an American Pain Society/ American College of Physicians clinical practice guideline. Annals of internal medicine. 2007 Oct 2;147(7):492-504.

5. Meucci RD, Fassa AG, Paniz VM, Silva MC, Wegman DH. Increase of chronic low back pain prevalence in a medium-sized city of southern Brazil. BMC musculoskeletal disorders. 2013 Dec;14(1):1-1.

6. Meucci RD, Fassa AG, Faria NM. Prevalence of chronic low back pain: systematic review. Revista de saude publica. 2015 Oct 20;49:73.

7. Ebnezar J, Nagarathna R, Bali Yogitha HR. Effect of integrated yoga therapy on pain, morning stiffness and anxiety in osteoarthritis of the knee joint: a randomized control study. International Journal of Yoga. 2012 Jan;5(1):28.

8. Macphail K. C-reactive protein, chronic low back pain and, diet and lifestyle. International Musculoskeletal Medicine. 2015 Apr 1;37(1): 29-32.

9. Blödt S, Pach D, Roll S, Witt CM. Effectiveness of app-based relaxation for patients with chronic low back pain (Relaxback) and chronic neck pain (Relaxneck): study protocol for two randomized pragmatic trials. Trials. 2014 Dec;15(1):1-9.

10. Smith MD, Russell A, Hodges PW. Disorders of breathing and continence have a stronger association with back pain than obesity and physical activity. Australian Journal of Physiotherapy. 2006 Jan 1;52(1): 11-6.

11. Tilbrook HE, Cox H, Hewitt CE, Kang'ombe AR, Chuang LH, Jayakody S, Aplin JD, Semlyen A, Trewhela A, Watt I, Torgerson DJ. Yoga for chronic low back pain: a randomized trial. Annals of internal medicine. 2011 Nov 1;155(9):569-78.

12. Konrad K, Tatrai T, Hunka A, Vereckei E, Korondi I. Controlled trial of balneotherapy in treatment of low back pain. Annals of the rheumatic diseases. 1992 Jun 1;51(6):820-2.

13. Hurley DA, Minder PM, McDonough SM, Walsh DM, Moore AP, Baxter DG. Interferential therapy electrode placement technique in acute low back pain: a preliminary investigation. Archives of physical medicine and rehabilitation. 2001 Apr 1;82(4):485-93.

14. Ebadi S, Henschke N, Nakhostin Ansari N, Fallah E, van Tulder MW. Therapeutic ultrasound for chronic low-back pain. Cochrane Database Syst Rev. 2014 Mar 14;(3):CD009169. 